\title{
OBSERVATIONS ON THE EARLY ELEVATION OF SERUM POTASSIUM DURING RESPIRATORY ALKALOSIS ${ }^{1}$
}

\author{
By JOHN B. HICKAM, WILLIAM P. WILSON, AND REGINA FRAYSER \\ (From The Departments of Medicine and Psychiatry, Duke University School of Medicine, \\ Durham, N. C.)
}

(Submitted for publication October 31, 1955 ; accepted February 9, 1956)

Respiratory alkalosis has been reported to cause both an increase and a decrease in serum potassium concentration, with the direction of the change depending upon the duration of alkalosis. Voluntary hyperventilation for 3 to 6 minutes has been found to cause an average increase of 0.5 $\mathrm{mEq}$. per $\mathrm{L}$. in the arterial serum potassium of normal subjects (1), but hyperventilation for 25 to 30 minutes causes a moderate fall in serum potassium (2-4). Over longer periods of time chronic passive hyperventilation was not found to produce a consistent change in arterial serum potassium in man (5), although it causes a drop in the serum potassium concentration of the dog $(6,7)$.

The decrease in serum potassium concentration which eventually develops during respiratory alkalosis reflects the movement of potassium from an extracellular to an intracellular position as part of an ionic transfer which has the effect of buffering extracellular fluid $(4,6,8)$. The initial increase in serum potassium during respiratory alkalosis does not have this effect and appears paradoxical. Because epinephrine can cause a transient rise in serum potassium, it has been suggested that the potassium rise during respiratory alkalosis may be mediated by secretion of epinephrine (1).

It is the purpose of this report to describe some observations on the elevation of serum potassium during acute respiratory alkalosis, with particular attention to the early time-course of the changes, the source of the additional potassium, and the causative role of epinephrine.

\section{METHODS}

The normal subjects were male medical students, physicians, and hospital patients without known organic

1 This investigation was supported (in part) by a research grant (Public Health Service H-1370) from the National Heart Institute of the National Institutes of Health, Public Health Service, and (in part) by the Life Insurance Medical Research Fund. disease at the time of study. The age range was from 23 to 49 years. All observations were made with the subjects recumbent after a rest period of 10 to $15 \mathrm{~min}$ utes. Vigorous, voluntary hyperventilation was carried out at a rate as uniform as possible for periods of approximately 2 minutes. Arterial blood samples were obtained from the femoral or brachial artery, jugular samples from the jugular bulb, and hepatic venous samples by way of an intravenous catheter. The sampling times given in the text are at the approximate mid-points of the sampling periods, which usually occupied 10 to 20 seconds.

The $\mathrm{pH}$ of whole blood was measured with a Cambridge Model $\mathrm{R} \mathrm{pH}$ meter equipped with an inclosed glass electrode. Measurements were made at room temperature, usually 25 to $26^{\circ} \mathrm{C}$., and the result was corrected to $37^{\circ} \mathrm{C}$. by Rosenthal's factor (9). The per cent oxygen saturation of blood was measured by a photometric method (10). The carbon dioxide content of whole blood was determined by the method of Van Slyke and Neill (11), and the plasma carbon dioxide content was estimated from this value and from the $\mathrm{pH}$, hemoglobin concentration, and per cent oxygen saturation by the line chart of Van Slyke and Sendroy (12). The plasma $\mathrm{CO}_{2}$ tension was calculated by the HendersonHasselbalch equation, using a $\mathrm{pK}^{\prime}$ of 6.11 (13). The whole blood buffer base was estimated from the nomogram of Singer and Hastings (14). Serum potassium was measured with an internal standard flame photometer (15). Duplicate determinations using different serum dilutions showed a mean difference of 0.9 per cent (S.D. \pm 0.7 per cent). Blood glucose was measured by the method of Nelson (16).

\section{RESULTS}

The data obtained during brief, vigorous hyperventilation are presented in Table I. The mean arterial serum potassium concentration increased from $4.0 \mathrm{mEq}$. per $\mathrm{L}$. at rest to $5.2 \mathrm{mEq}$. per L. after 2 minutes of hyperventilation. After hyperventilation, the serum potassium rapidly fell toward the control level.

In several subjects measurements were also made of the serum potassium in venous blood from various sites. As shown in Table I, venous potassium was higher than arterial potassium in the hepatic vein, but was lower in the 


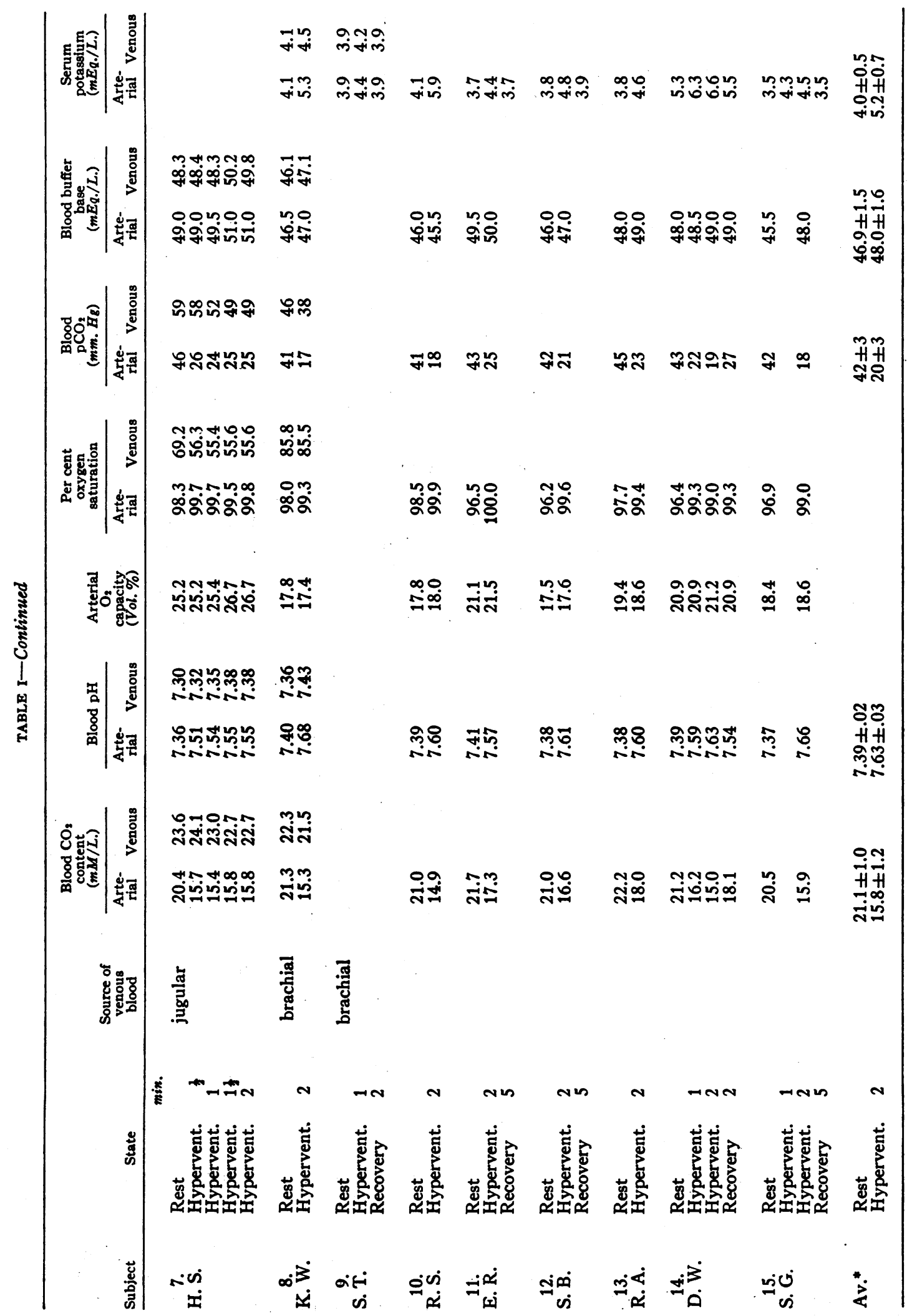


jugular and brachial veins. After 2 minutes of hyperventilation the mean increase in hepatic venous potassium was $2.1 \mathrm{mEq}$. per $\mathrm{L}$. in four subjects, while the simultaneous increase in arterial potassium was $1.2 \mathrm{mEq}$. per L. These findings indicate that potassium is being added to the blood in the splanchnic region and removed from the blood in brain and arm. The data are not adequate to conclude that the splanchnic region is the only significant source of the serum potassium rise during early hyperventilation.

Since serum potassium is known to be elevated by brief vigorous exercise (17), measurements of arterial serum potassium were made in two subjects (Nos. 8 and 13) during hyperventilation on 7 per cent and 10 per cent $\mathrm{CO}_{2}$ to prevent respiratory alkalosis. Neither subject showed a significant change in potassium concentration during this procedure, although both had the usual rise in serum potassium during hyperventilation on air.

Some experiments were conducted to explore the possibility that liberation of potassium from the splanchnic region during hyperventilation might be mediated by epinephrine or nor-epinephrine. No evidence was obtained for such mediation. As shown by the data in Table II, hyperventilation and $.040 \mathrm{mg}$. of epinephrine intravenously have diverse effects upon serum potas-

TABLE II *

Diverse effects of hyperventilation and intravenous epinephrine on arterial serum potassium and blood glucose concentration in two normal subjects

\begin{tabular}{|c|c|c|c|}
\hline Subject & State & $\begin{array}{c}\text { Arterial } \\
\text { serum } \\
\text { potassium } \\
(m E q . / L .)\end{array}$ & $\begin{array}{c}\text { Arterial } \\
\text { blood } \\
\text { glucose } \\
(m g . \%)\end{array}$ \\
\hline \multirow{3}{*}{ S. B. } & $\begin{array}{l}\text { Rest } \\
\text { Hyperventilation, } 2 \text { min. } \\
\text { Recovery, } 5 \text { min. }\end{array}$ & $\begin{array}{l}3.8 \\
4.8 \\
3.9\end{array}$ & $\begin{array}{l}80 \\
80 \\
82\end{array}$ \\
\hline & \multirow{3}{*}{$\begin{array}{l}\text { Rest approx. } 30 \mathrm{~min} \text {. } \\
2 \mathrm{~min} \text {. after } .040 \mathrm{mg} \text {. } \\
\text { epinephrine i.v. } \\
7 \text { min. after .040 mg. } \\
\text { epinephrine i.v. }\end{array}$} & 3.9 & 84 \\
\hline & & 4.0 & 84 \\
\hline & & 3.9 & 94 \\
\hline & $\begin{array}{l}\text { Rest } \\
2 \mathrm{~min} \text {, after } .040 \mathrm{mg} .\end{array}$ & $-\overline{3.8}$ & 70 \\
\hline \multirow{3}{*}{ E. R. } & $\begin{array}{l}\text { epinephrine i.v. } \\
7 \mathrm{~min} \text {. after } .040 \mathrm{mg} \text {. }\end{array}$ & 3.8 & 70 \\
\hline & epinephrine i.v. & 3.8 & 85 \\
\hline & $\begin{array}{l}\text { Rest approx. } 30 \mathrm{~min} . \\
\text { Hyperventilation, } 2 \text { min. } \\
\text { Recovery, } 5 \text { min. }\end{array}$ & $\begin{array}{l}3.7 \\
4.4 \\
3.7\end{array}$ & $\begin{array}{l}80 \\
80 \\
82\end{array}$ \\
\hline
\end{tabular}

* Serum potassium values during hyperventilation are those reported in Table I for these subjects. sium and blood glucose. Hyperventilation elevates serum potassium without changing blood glucose, while epinephrine in these doses elevates blood glucose without changing serum potassium. The epinephrine infusion occupied 30 seconds, and the first samples were drawn 2 minutes after the start of the infusion. Observations were also made on two subjects with defects which should have interfered markedly with their production of epinephrine and nor-epinephrine. An adult woman who had undergone a bilateral adrenalectomy for Cushing's syndrome demonstrated a serum potassium elevation of $0.8 \mathrm{mEq}$. per L. after $1-1 / 2 \mathrm{~min}$ utes of hyperventilation. A middle-aged man with severe, idiopathic postural hypotension and a nearly fixed heart rate had a serum potassium elevation of $0.6 \mathrm{mEq}$. per $\mathrm{L}$. after $1-1 / 2$ minutes of hyperventilation. Hyperventilation did not alter this patient's heart rate, but he was so sensitive to epinephrine that the intravenous administration of $.003 \mathrm{mg}$. of epinephrine provoked a transient episode of auricular fibrillation.

Concomitant with the rise in serum potassium during hyperventilation, the normal subjects showed a small mean increase in arterial whole blood buffer base. The change amounted to 1.1 $\mathrm{mEq}$. per L. (Table I). This increase was statistically significant $(P<.01)$. In four subjects this result was confirmed by measuring directly the extent of shift induced in the arterial blood $\mathrm{CO}_{2}$ dissociation curve by 2 minutes of hyperventilation. For this measurement the $\mathrm{CO}_{2}$ dissociation curve of arterial blood from the resting subject was laid out as a straight line on log-log paper, utilizing at least 3 points, one of which was close to the $\mathrm{CO}_{2}$ tension reached during hyperventilation. For obtaining these points arterial blood from the resting subject was equilibrated in tonometers at appropriate $\mathrm{CO}_{2}$ tensions, and the resultant $\mathrm{CO}_{2}$ content and $\mathrm{pH}$ were measured. The values actually obtained for arterial blood $\mathrm{CO}_{2}$ tension and content after hyperventilation for 2 minutes lay in each case on the alkaline side of this "in vitro" curve. That is, for the $\mathrm{CO}_{2}$ tensions which were reached during hyperventilation, the actual $\mathrm{CO}_{2}$ contents were always greater than those predicted by the curve. For the four subjects after 2 minutes of hyperventilation the actual $\mathrm{CO}_{2}$ contents exceeded the predicted by a mean of $1.4 \mathrm{mEq}$. per $\mathrm{L}$. The differences were 
2.3, $0.9,1.1$, and $1.4 \mathrm{mEq}$. per L. for subjects No. $6,8,13$, and 14 , respectively. Venous blood from the various sites which were sampled also showed a small increase in whole blood buffer base during hyperventilation.

\section{DISCUSSION}

These findings confirm the report (1) that serum potassium is elevated early in respiratory alkalosis. The present observations were made earlier in the course of alkalosis than those which have been reported before, and the increase in potassium is somewhat greater. During this time potassium is being added to the circulating blood from the splanchnic region, and is being removed from the blood in the brain and peripheral tissues, so far as the arm is representative of these. The present data provide no evidence as to potassium exchanges elsewhere. Later in respiratory alkalosis the serum potassium concentration falls below the resting levels as potassium moves from an extracellular to an intracellular position $(4,6,8)$.

There is abundant evidence that epinephrine and related substances can cause a transient elevation in the serum potassium concentration of man and various experimental animals (18-20), and D'Silva (21) showed that epinephrine will induce liberation of potassium from the perfused cat's liver. However, the present findings do not support the suggestion that the serum potassium elevation of respiratory alkalosis may be mediated by epinephrine or nor-epinephrine. In man, large doses of epinephrine are required to produce a transient elevation of serum potassium, and the potassium concentration then declines below the control level (18). No such decline occurred after brief periods of respiratory alkalosis. No changes in blood glucose were observed. Respiratory alkalosis induced a rise in the serum potassium concentration of an adrenalectomized subject and a subject with idiopathic postural hypotension. Luft and von Euler (22) have found that persons with postural hypotension excrete much less epinephrine and nor-epinephrine in response to appropriate stimuli than do normal subjects. This evidence indicates that potassium elevation occurs in normal subjects during respiratory alkalosis without the collateral effects which might be expected if it were mediated by epinephrine, and that the elevation can occur in subjects whose ability to produce epinephrine and nor-epinephrine is greatly impaired.

The rise in serum potassium which occurs in man when the blood $\mathrm{pH}$ is abruptly elevated above normal levels by hyperventilation somewhat suggests the hyperkalemia which occurs in experimental animals when severe respiratory acidosis is abruptly terminated. In the cat (23) and in the $\operatorname{dog}(24-26)$ severe respiratory acidosis, caused by breathing high concentrations of $\mathrm{CO}_{2}$, will cause a considerable increase in serum potassium. When the blood $\mathrm{pH}$ is abruptly raised toward normal levels by removing the animal to air, marked further hyperkalemia can occur. In the dog (26), potassium has been found to be released from the liver during this time, but in the cat (23) the phenomenon occurs even after splanchnic evisceration.

During early hyperventilation the $\mathrm{CO}_{2}$ dissociation curve of whole blood shifts to a more alkaline position and, correspondingly, there is a modest increase in whole blood buffer base concentration. The increase in serum potassium would certainly contribute toward this change, but other, undetermined, ionic transfers may be quite important. Shock and Hastings (27), using finger blood, found no change in the $\mathrm{CO}_{2}$ dissociation curve during hyperventilation, but most of their observations dealt with longer periods of hyperventilation, lasting 6 to 20 minutes. Nims, Gibbs, and Lennox (28) found an apparent shift of jugular venous blood to the alkaline side of the in vitro $\mathrm{CO}_{2}$ dissociation curve during hyperventilation, but believed that the arterial blood showed no such change. In the present study, arterial and jugular venous blood showed similar increases in buffer base concentration.

\section{SUMMARY AND CONCLUSIONS}

1. In normal subjects acute respiratory alkalosis induced by hyperventilation causes a transitory hyperkalemia. In 13 subjects the mean increase in arterial serum potassium was $1.2 \mathrm{mEq}$. per L. after 2 minutes of hyperventilation.

2. During early respiratory alkalosis potassium is added to the circulating blood in the splanchnic region.

3. During early respiratory alkalosis there is a small increase in whole blood buffer base. 


\section{REFERENCES}

1. Rapoport, S., Stevens, C. D., Engel, G. L., Ferris, E. B., and Logan, M., The effect of voluntary overbreathing on the electrolyte equilibrium of arterial blood in man. J. Biol. Chem., 1946, 163, 411.

2. Stanbury, S. W., and Thomson, A. E., The renal response to respiratory alkalosis. Clin. Sc., 1952, 11,357 .

3. Singer, R. B., Elkinton, J. R., Barker, E. S., and Clark, J. K., Transfers of cellular cations during acute respiratory alkalosis and acidosis experimentally produced in man. J. Clin. Invest., 1953, 32, 604.

4. Elkinton, J. R., Singer, R. B., Barker, E. S., and Clark, J. K., Effects in man of acute experimental respiratory alkalosis and acidosis on ionic transfers in the total body fluids. J. Clin. Invest., 1955, 34, 1671.

5. Brown, E. B., Jr., Campbell, G. S., Elam, J. O., Gollan, F., Hemingway, A., and Visscher, M. B., Electrolyte changes with chronic passive hyperventilation in man. J. Applied Physiol., 1949, 1, 848.

6. Giebisch, G., Berger, L., and Pitts, R. F., The extrarenal response to acute acid-base disturbances of respiratory origin. J. Clin. Invest., 1955, 34, 231.

7. Scribner, B. H., and Burnell, J. M., The effect of respiratory alterations of $\mathrm{pH}$ on the internal equilibrium of potassium. J. Clin. Invest., 1955, 34, 919.

8. Scribner, B. H., Fremont-Smith, K., and Burnell, J. M., The effect of acute respiratory acidosis on the internal equilibrium of potassium. J. Clin. Invest., 1955, 34, 1276.

9. Rosenthal, T. B., The effect of temperature on the $\mathrm{pH}$ of blood and plasma in vitro. J. Biol. Chem., 1948, 173, 25.

10. Hickam, J. B., and Frayser, R., Spectrophotometric determination of blood oxygen. J. Biol. Chem., 1949, 180, 457.

11. Van Slyke, D. D., and Neill, J. M., The determination of gases in blood and other solutions by vacuum extraction and manometric measurements. I. J. Biol. Chem., 1924, 61, 523.

12. Van Slyke, D. D., and Sendroy, J., Jr., Studies of gas and electrolyte equilibria in blood. XV. Line charts for graphic calculations by the HendersonHasselbalch equation, and for calculating plasma carbon dioxide content from whole blood content. J. Biol. Chem., 1928, 79, 781.

13. Dill, D. B., Daly, C., and Forbes, W. H., The $\mathrm{pK}^{\prime}$ of serum and red cells. J. Biol. Chem., 1937, 117, 569.
14. Singer, R. B., and Hastings, A. B., An improved clinical method for the estimation of disturbances of the acid-base balance of human blood. Medicine, 1948, 27, 223.

15. White, J. U., Precision of a simple flame photometer. Analytical Chem., 1952, 24, 394.

16. Nelson, N., A photometric adaptation of the Somogyi method for the determination of glucose. J. Biol. Chem., 1944, 153, 375.

17. Keys, A., Exchanges between blood plasma and tissue fluid in man. Science, 1937, 85, 317.

18. Brewer, G., Larson, P. S., and Schroeder, A. R., On the effect of epinephrine on blood potassium. Am. J. Physiol., 1939, 126, 708.

19. O'Brien, G. S., Murphy, Q. R., Jr., and Meek, W. J., The effect of sympathomimetic amines on arterial plasma potassium and cardiac rhythm in anesthetized dogs. J. Pharmacol. \& Exper. Therap., 1953, 109, 453.

20. Muirhead, E. E., Goth, A., and Jones, F., Sodium and potassium exchanges associated with nor-epinephrine infusions. Am. J. Physiol., 1954, 179, 1.

21. D'Silva, J. L., Action of adrenaline on the perfused liver. J. Physiol., 1936, 87, 181.

22. Luft, R., and von Euler, U. S., Two cases of postural hypotension showing a deficiency in release of nor-epinephrine and epinephrine. J. Clin. Invest., 1953, 32, 1065.

23. MacKay, J. L., Effects of a narcotic level of carbon dioxide on the plasma potassium and respiration of cats. Am. J. Physiol., 1947, 151, 469.

24. Young, W. G., Jr., Sealy, W. C., and Harris, J. S., The role of intracellular and extracellular electrolytes in the cardiac arrhythmias produced by prolonged hypercapnia. Surgery, 1954, 36, 636.

25. Scribner, B. H., Bogardus, G. M., Fremont-Smith, K., and Burnell, J. M., Potassium intoxication during and immediately following respiratory acidosis. J. Clin. Invest., 1954, 33, 965.

26. Joyner, S. B., Davis, D. A., Young, D. T., Craige, E., and Welt, L. G., An analysis of the chemical events and their interrelationships with alterations in the ECG during respiratory acidosis and alkalosis. J. Clin. Invest., 1955, 34, 974.

27. Shock, N. W., and Hastings, A. B., Studies of the acid-base balance of the blood. IV. Characterization and interpretation of displacement of the acidbase balance. J. Biol. Chem., 1935, 112, 239.

28. Nims, L. F., Gibbs, E. L., and Lennox, W. G., Arterial and cerebral venous blood changes produced by altering arterial carbon dioxide. J. Biol. Chem., 1942, 145, 189. 